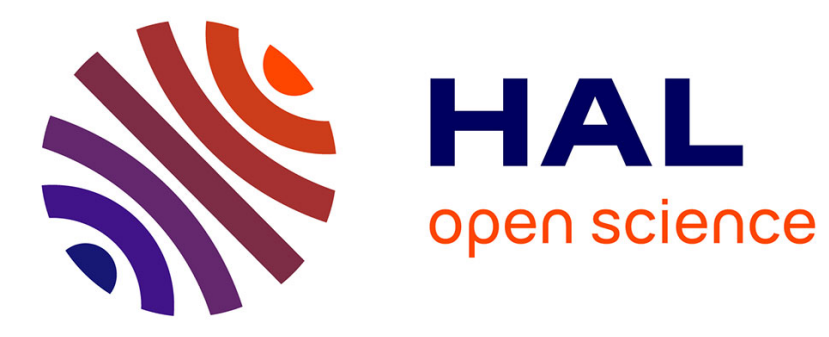

\title{
Precipitation in original Duralumin A-U4G versus modern 2017A alloy
}

Magali Brunet, Benoit Malard, Nicolas Ratel-Ramond, Christophe Deshayes, Sébastien Joulié, Bénédicte Warot-Fonrose, Philippe Sciau, Joël Douin, Frédéric de Geuser, Alexis Deschamps

\section{To cite this version:}

Magali Brunet, Benoit Malard, Nicolas Ratel-Ramond, Christophe Deshayes, Sébastien Joulié, et al.. Precipitation in original Duralumin A-U4G versus modern 2017A alloy. Materialia, 2019, 8, pp.100429. 10.1016/j.mtla.2019.100429 . hal-02269041

\section{HAL Id: hal-02269041 https://hal.science/hal-02269041}

Submitted on 22 Aug 2019

HAL is a multi-disciplinary open access archive for the deposit and dissemination of scientific research documents, whether they are published or not. The documents may come from teaching and research institutions in France or abroad, or from public or private research centers.
L'archive ouverte pluridisciplinaire HAL, est destinée au dépôt et à la diffusion de documents scientifiques de niveau recherche, publiés ou non, émanant des établissements d'enseignement et de recherche français ou étrangers, des laboratoires publics ou privés. 


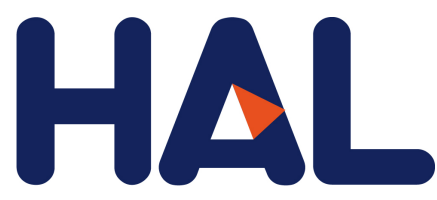

archives-ouvertes

\section{Precipitation in original Duralumin A-U4G versus modern 2017A alloy}

Magali Brunet, Benoit Malard, Nicolas Ratel-Ramond, Christophe Deshayes, Sébastien Joulié, Bénédicte Warot-Fonrose, Philippe Sciau, Joël Douin, Frédéric de Geuser, Alexis Deschamps

\section{To cite this version:}

Magali Brunet, Benoit Malard, Nicolas Ratel-Ramond, Christophe Deshayes, Sébastien Joulié, et al.. Precipitation in original Duralumin A-U4G versus modern 2017A alloy. Acta Materialia, Elsevier, 2019, 8, pp.100429. 10.1016/j.mtla.2019.100429 . hal-02269041

\section{HAL Id: hal-02269041 \\ https://hal.archives-ouvertes.fr/hal-02269041}

Submitted on 22 Aug 2019

HAL is a multi-disciplinary open access archive for the deposit and dissemination of scientific research documents, whether they are published or not. The documents may come from teaching and research institutions in France or abroad, or from public or private research centers.
L'archive ouverte pluridisciplinaire HAL, est destinée au dépôt et à la diffusion de documents scientifiques de niveau recherche, publiés ou non, émanant des établissements d'enseignement et de recherche français ou étrangers, des laboratoires publics ou privés. 


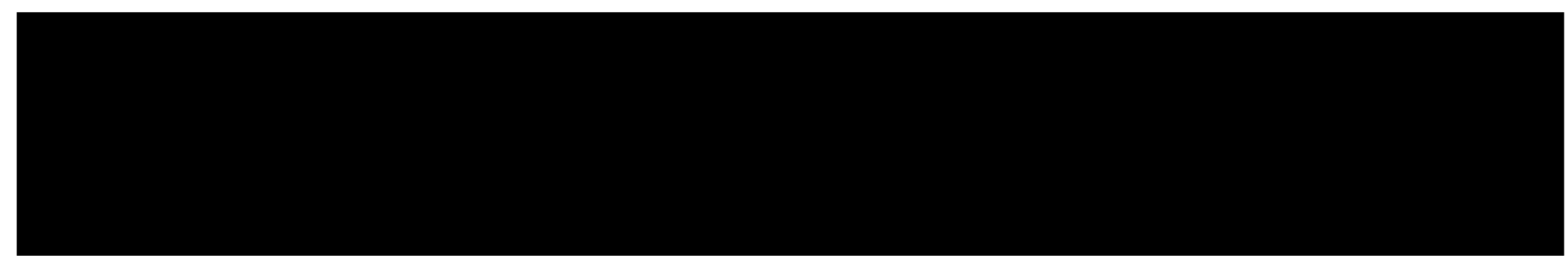

Full Length Article

\title{
Precipitation in original Duralumin A-U4G versus modern 2017A alloy
}

\author{
Alexis Deschamps ${ }^{c}$ \\ ${ }^{a}$ CEMES, CNRS, Université de Toulouse, 29 rue Jeanne Marvig, BP 9434731055 Toulouse Cedex 4, France \\ ${ }^{\mathrm{b}}$ CIRIMAT, INP Toulouse, CNRS, 4 allée Emile Monso, 31030 Toulouse, France \\ c Université Grenoble Alpes, CNRS, Grenoble INP, SIMaP, F-38000 Grenoble, France
}

Magali Brunet $^{\mathrm{a}, *}$, Benoit Malard ${ }^{\mathrm{b}}$, Nicolas Ratel-Ramond ${ }^{\mathrm{a}}$, Christophe Deshayes ${ }^{\mathrm{a}}$, Sébastien Joulié ${ }^{a}$, Bénédicte Warot-Fonrose ${ }^{a}$, Philippe Sciau ${ }^{a}$, Joël Douin ${ }^{a}$, Frédéric De Geuser ${ }^{c}$,

\section{A R T I C L E I N F O}

\section{Keywords:}

Duralumin

$\mathrm{Al}-\mathrm{Cu}-\mathrm{Mg}-\mathrm{Si}$ alloy

Precipitation

SAXS

STEM-HAADF

\begin{abstract}
A B S T R A C T
Precipitation in Duralumin, a historic quaternary alloy of the type: $\mathrm{Al}-\mathrm{Cu}-\mathrm{Mg}-\mathrm{Si}$, was never fully studied nor observed by current electron microscopy techniques. This article presents the full characterization and comparison of two alloys: a Duralumin (A-U4G) from the 1950s collected on a vintage aircraft and its modern equivalent: a 2017A alloy. The as-received and peak-aging states were analysed with DSC, SAXS and TEM advanced techniques. It is shown that old Duralumin and modern 2017A present a similar nanoprecipitation in the as-received state and behave similarly upon artificial aging. As opposed to what has been reported in the past, three types of precipitates participating in hardening were found upon aging: $\theta^{\prime}-\mathrm{Al}_{2} \mathrm{Cu}, \mathrm{Q}$ '(Q)-AlCuMgSi and $\Omega-\mathrm{Al}_{2} \mathrm{Cu}$.
\end{abstract}

\section{Introduction}

Duralumin, with a composition close to $4 \mathrm{Cu}-0.7 \mathrm{Mg}-0.6 \mathrm{Mn}-0.6$ $\mathrm{Si}$ wt\%, is the oldest age-hardening aluminium alloy. Discovered in 1906 by Alfred Wilm, a German metallurgist [1], it triggered the development of aeronautics at the beginning of the XXth century. At the scientific and technical research centre in Neubabelsberg, Wilm experimented many treatments on Al-Cu-Mn alloys with small amounts of magnesium $(0.5 \mathrm{wt} \%)$. He found out that by quenching from temperatures below its melting point (about $450{ }^{\circ} \mathrm{C}$ ) and by letting it age naturally for a few days, the new alloy exhibited enhanced mechanical properties (strength and hardness). Thanks to its low density and strength, Duralumin soon became the prime choice for airplanes construction, well-illustrated by the airplane Breguet 14 whose production reached 12,000 during World War I [2]. From then on, aircraft production, previously a craftsmen business, transformed into a real industry. Following on this discovery and for reaching even higher performance, metallurgists in the 1920s tuned aluminium alloys via the addition of microalloying elements. This was done empirically, as no explanation could yet be provided for the age-hardening phenomenon. Merica et al. [3] were the first team in 1929 to explain that the hardening during aging of duralumin was due to fine and highly dispersed $\mathrm{Al}_{2} \mathrm{Cu}$ precipitates. But the concept of dislocation, essential to a complete understanding of the structural hardening mechanism, was introduced by Orowan in 1934 [4]. The discovery of coherent copper-rich zones in the Al-Cu $4 \%$ alloy was achieved independently by Guinier [5] and Preston [6] with $\mathrm{X}$-ray experiments in 1938. It took even longer to be able to observe directly the nanoprecipitates responsible for the hardening: first observations were made on oxide replicas in France in 1952 by Saulnier and Syre [7].

Original Duralumin was thus improved experimentally by increasing the magnesium content (up to $1.5 \mathrm{wt} \%$ ), leading to a new alloy, called Duralumin FR in France in the early 1930s [8]. Duralumin and Duralumin FR became A-U4G and A-U4G1 respectively in 1943, to follow a new designation defined by AFNOR ${ }^{1}$ [9]. From the 1930s to the 1950s, because of its lack of strength and ductility, A-U4G was replaced gradually in aeronautics construction by A-U4G1. In 1954, international standardization of aluminium alloys took place [10]: the numerical designation with 4 numbers was adopted. A-U4G was designated as 2017A and A-U4G1 as the well-known 2024.

Original Duralumin has not received a major focus in the scientific literature related to the precipitation at nanoscale. In fact, published works on the precipitation occurring in Duralumin and even on the modern 2017A alloys are scarce. Original studies on the precipitation of industrial Duralumin were published in the 1950s. In 1950, Lambot studied the precipitation of an industrial Duralumin by X-ray abnormal scattering [11]. In accordance with results found by Guinier and Preston in $\mathrm{Al}-\mathrm{Cu}$ alloys, after quenching and room temperature aging, he detected scattering due to copper clusters or Guinier Preston Zones (GPZ). Then, upon aging at moderate temperatures, a first form of precipitates was evidenced, with a structure of three aluminium-rich planes

\footnotetext{
1 Created in 1926, AFNOR is the French association for standardization.
}

* Corresponding author. 
Table 1

Elemental composition of alloys (in wt \%) obtained by ICP-OES.

\begin{tabular}{lllllllll}
\hline & $\mathrm{Al}$ & $\mathrm{Cu}$ & $\mathrm{Mg}$ & $\mathrm{Mn}$ & $\mathrm{Si}$ & $\mathrm{Fe}$ & $\mathrm{Ti}$ & $\mathrm{Cr}$ \\
\hline 2017A & Base & $4.32 \pm 0.08$ & $0.68 \pm 0.01$ & $0.611 \pm 0.002$ & $0.618 \pm 0.006$ & $0.34 \pm 0.01$ & $0.043 \pm 0.001$ & $0.20 \pm 0.04$ \\
A-U4G & Base & $4.18 \pm 0.04$ & $0.710 \pm 0.005$ & $0.67 \pm 0.01$ & $0.61 \pm 0.01$ & $0.285 \pm 0.008$ & $0.010 \pm 0.001$ & $0.082 \pm 0.008$ \\
\hline
\end{tabular}

in between two copper-rich planes. This phase evolved to the welldistinguished $\theta^{\prime}-\mathrm{Al}_{2} \mathrm{Cu}$ phase when aging at higher temperatures. Other scattering patterns, superimposed to the ones originating from $\mathrm{Al}_{2} \mathrm{Cu}$ precipitates, were detected. They were attributed to the $\mathrm{Al}_{4} \mathrm{CuMg}_{5} \mathrm{Si}_{4}$ phase. This phase is expected at equilibrium state, in alloys of $\mathrm{Mg} / \mathrm{Si}$ ratios lower than 1.73 [12]. Two years later, Saulnier and Syre [7] identified in a similar industrial Duralumin, thanks to electron microscopy (using oxide replicas), the presence of the so-called phase $\mathrm{X}$ (renamed $\theta$ " later) after aging at $260^{\circ} \mathrm{C}$ evolving into the $\theta^{\prime}-\mathrm{Al}_{2} \mathrm{Cu}$ phase at $290^{\circ} \mathrm{C}$, confirming the findings of Lambot. Another phase was evidenced with thermal dilatometry. However, it was attributed to $\mathrm{Mg}_{2} \mathrm{Si}$ needles. In this work, the Q- $\mathrm{Al}_{4} \mathrm{CuMg}_{5} \mathrm{Si}_{4}$ phase could not be evidenced. Similarly, Yano and Koda in 1968 [13], observed by transmission electron microscopy (TEM), the presence of the $\theta^{\prime}-\mathrm{Al}_{2} \mathrm{Cu}$ and $\mathrm{Mg}_{2} \mathrm{Si}$ phases in Duralumin. More recently, Härtel et al. [14] studied the 2017A alloy and observed the $\theta$ ' phase and another phase, $\Omega$-AlCu. However, they did not mention the presence of Q-AlCuMgSi, neither $\mathrm{Mg}_{2} \mathrm{Si}$. It is to be noted though that the silicon content was, in their case, very low $(0.08 \mathrm{wt} \%)$. As shown here, literature does not provide a clear and comprehensive report on precipitation occurring in Duralumin.

This article focuses on the observation and identification of the metastable phases and precipitation sequences occurring in a Duralumin (A-U4G) of 1958 collected on an old aircraft and aged at ambient temperature for more than 60 years. It will be compared to a modern equivalent, the 2017A alloy. When looking at the international standards [10], it is interesting to note that, as opposed to the A-U4G1 which composition is significantly different from the modern equivalent 2024, the composition of A-U4G/2017A has barely evolved over time. As the collected Duralumin is more than 60 years old, by comparing its behaviour and microstructure to the modern equivalent, it is also the occasion to study long-term aging on this type of alloy. This constitutes a first motivation for studying this alloy. The second motivation is related to Cultural Heritage. Duralumin constitutes most of the airplanes' fuselage and structure before and during World War II. Precious specimens conserved in Museum should be preserved. By understanding and documenting the intrinsic constitution of the alloy and its behaviour over time, it will be easier to anticipate problems such as lack of mechanical resistance and/or corrosion.

The microstructure of the A-U4G and 2017A in different states, asreceived and after artificial aging, will be reported hereafter by combining different techniques: conventional bright and dark field TEM, selected area diffraction patterns (SADP), scanning transmission electron microscopy coupled with energy dispersive X-ray spectroscopy (STEMEDS), with high angle annular dark field (HAADF) imaging or with electron energy loss spectroscopy (EELS), differential scanning calorimetry (DSC) and small angle X-ray scattering (SAXS) experiments. It is shown that, compared to what could be expected from the literature on quaternary $\mathrm{Al}-\mathrm{Cu}-\mathrm{Mg}-\mathrm{Si}$ alloys $[15,16]$ with a range of $2.5-4.5 \mathrm{wt} \%$ of copper, and a ratio of $\mathrm{Mg}: \mathrm{Si}$ close to 1 or what was observed in the $1950 \mathrm{~s}$ and 1960s on Duralumin [7,13], a complex and specific precipitation sequence occurs in these alloys.

\section{Materials and characterization techniques}

\subsection{Materials}

The studied alloy is a Duralumin, identified as A-U4G in the shape of plate (about $1 \mathrm{~mm}$ thick) collected on an aircraft from 1958, a Breguet Sahara 765: the sample was extracted from a flap of the landing gear, a part not subjected to hot temperatures related to engine proximity (see Fig. S1 of supplementary information). The equivalent modern alloy, EN AW-2017A (labelled hereafter 2017A) was bought from Bikar Metalle GmbH. It was received in T4 state. In general, for 2017A and 2024 alloys, the states T3 and T4 are common for parts of low thickness $(<12 \mathrm{~mm})$. In these states, the alloy exhibits a good corrosion resistance, a high toughness and a good fatigue resistance [17]. The plate collected on the plane received also a T4 treatment upon fabrication: it was clearly mentioned in the Breguet standards [18]. However, for this alloy, the asreceived state corresponds in fact, to a $\mathrm{T} 4$ state plus 10 years of service and 50 years in outdoors conditions.

For each alloy, the inductively coupled plasma-optical emission spectrometry (ICP-OES) measurements, performed by Evans Analytical Group SAS, is reported in Table 1. It is confirmed that the compositions are similar. Currently, 2017A contains some zinc whereas old version of this alloy does not. The ratios $\mathrm{Mg}: \mathrm{Si}$ are 1.1 and 1.16 for 2017A and A-U4G, respectively, which correspond to reported values for Duralumin [7].

For the study of hardening precipitation, two states were compared: as-received and peak-aging conditions. To find peak-aging condition, received samples were heat-treated at $180^{\circ} \mathrm{C}$ during different times. The samples were then cut along three perpendicular directions relative to the rolling direction and measurements of micro-hardness (Vickers) were carried out in the corresponding planes (RP: rolling plane; NP: normal plane; TP: transverse plane).

\subsection{Characterization techniques}

The alloys were analysed by different techniques, which required adapted preparations. For hardness measurements as well as for the observation of the microstructure by optical microscope (OM) and scanning electron microscope (SEM), each specimen (in the 3 planes) was embedded in an epoxy resin and mechanically polished on waterlubricated abrasive papers (silicon carbide): P600 then P1200 and eventually on polishing cloths with diamond paste (from $3 \mu \mathrm{m}$ down to $1 \mu \mathrm{m})$.

For TEM observations, the preparation was the following: to bring the sample thickness down to $25 \mu \mathrm{m}$, a mechanical polishing with paper grade up to $2400 \mathrm{SiC}$, was performed. The specimens were then electrochemically thinned using a Tenupol-5 Struers apparatus operating at $60 \mathrm{~V}$ in a solution of methanol and nitric acid $(3: 1)$ at $-15^{\circ} \mathrm{C}$. Observations of the nanostructure were carried out on a JEOL 2010 operating at $200 \mathrm{kV}$. Bright field images were taken with an orientation slightly off the $[100]_{\mathrm{Al}}$ zone axis. Chemical elements were identified with a CM20 FEG TEM/STEM microscope, operating at $200 \mathrm{kV}$ and equipped with an energy dispersive X-ray spectroscopy (Quantax EDS system with silicon drift detector from Bruker). For EDS mapping, an area of $235 \times 88$ pixels was scanned with a probe size of about $5 \mathrm{~nm}$ and a high statistic (20 $000 \mathrm{cps).}$

HAADF scanning TEM micrographs of as-received and heat-treated samples were acquired using a JEOL cold-FEG JEM-ARM200F instrument operated at $200 \mathrm{kV}$ (energy resolution, $0.3 \mathrm{eV}$ ) and equipped with a probe Cs corrector with a spatial resolution of $0.078 \mathrm{~nm}$. To identify the phases and chemistry, energy electron loss spectroscopy (EELS) spectra were acquired using a GIF Quantum ER imaging filter, between 850 and $1850 \mathrm{eV}$ in order to include the $\mathrm{Cu}-\mathrm{L}_{2,3}(931-951 \mathrm{eV})$, the $\mathrm{Mg}-\mathrm{K}$ $(1305 \mathrm{eV})$, the $\mathrm{Si}-\mathrm{K}(1839 \mathrm{eV})$ and the $\mathrm{Al}-\mathrm{K}(1560 \mathrm{eV})$ edges. EELS was performed on line scans across precipitates as well as on some fixed positions. 


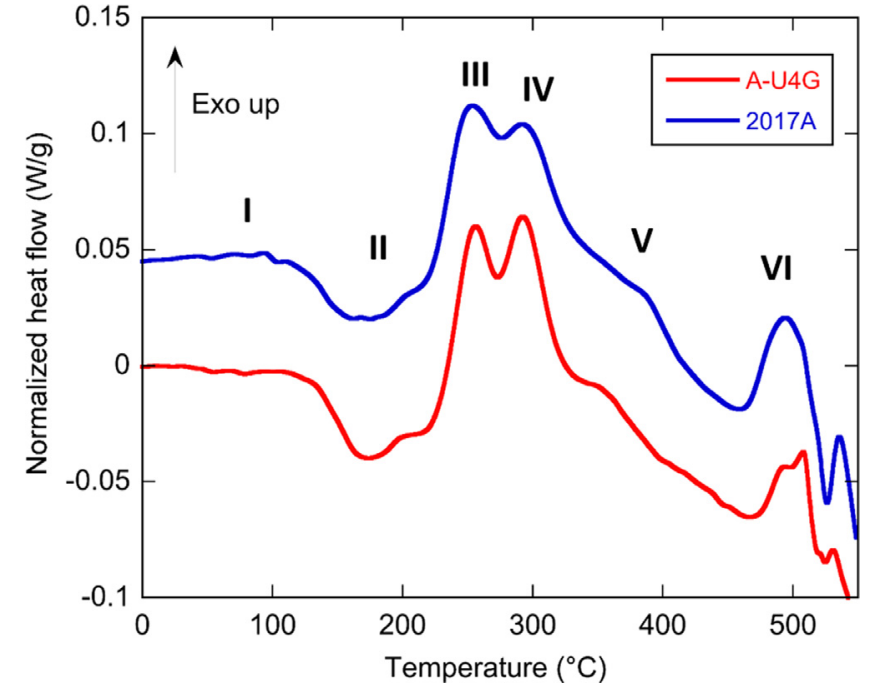

Fig. 1. DSC curves of A-U4G and 2017A, as-received state. The heating rate is $20^{\circ} \mathrm{C} / \mathrm{min}$. 2017A curve is shifted upward for a better visualisation.

DSC experiments were also carried out. For this, samples with a thickness of $1 \mathrm{~mm}$ and a weight of about $20 \mathrm{mg}$ were prepared. They were subjected to ramp heating between $-10^{\circ} \mathrm{C}$ and $550^{\circ} \mathrm{C}$ at $20^{\circ} \mathrm{C} / \mathrm{min}$ in a Mettler-Toledo DSC3+. Results were corrected for baseline and normalized for the sample weight.

SAXS measurements were performed on an Xeuss equipment proposed by Xenocs. The X-ray source is equipped with a $\mathrm{Cu}$ anode and the SAXS setup is equipped with anti-scattering slits and $6 \mathrm{M}$ Pilatus detector. The beam size is $1 \mathrm{~mm}^{2}$. For SAXS experiments, samples were thinned down to $100 \mu \mathrm{m}$. In order to investigate the large q-range available, 3 sample-to-detector distances were considered $(40 \mathrm{~cm}, 1.2 \mathrm{~m}$ and $2.5 \mathrm{~m}$ ). In addition, a fixed detector collected the intensity scattered at wide angles, and allowed to obtain the first diffraction peaks of the material. Transmission and background corrections were made using standard protocols. The quantitative analysis was carried out according to the approach described in a previous article [19].

\section{Results}

\subsection{As received state}

DSC results for A-U4G and 2017A in as-received state are presented in Fig. 1. Six different regions can be identified. Peaks are directly related to precipitates nucleation and growth in the alloy. The first region (I), from room temperature up to $150^{\circ} \mathrm{C}$ is flat. It is generally assumed that in this temperature range, Guinier-Preston zones should appear. Here, in the as-received alloys, GPZ are supposedly already formed. A second region (II) contains an endothermic peak between $150^{\circ} \mathrm{C}$ and $180^{\circ} \mathrm{C}$ and a small exothermic peak around $200^{\circ} \mathrm{C}$, ascribed to the dissolution of GPZ and the formation of $\theta$ " phase, respectively. The third and fourth regions (III and IV) exhibit two large exothermic peaks: one between $220^{\circ} \mathrm{C}$ and $280^{\circ} \mathrm{C}$ (III) and one between $280^{\circ} \mathrm{C}$ and $320^{\circ} \mathrm{C}$ (IV). In literature on $\mathrm{Al}-\mathrm{Cu}-\mathrm{Mg}-\mathrm{Si}$ alloys, these peaks were attributed to different phases. It was first observed by Saulnier and Syre [7] that an exothermic peak at $290^{\circ} \mathrm{C}$ coincided with the presence of the $\theta^{\prime}$ $\mathrm{Al}_{2} \mathrm{Cu}$ phase whereas the peak at $350^{\circ} \mathrm{C}$ was marked by the apparition of a needle shape precipitation, supposedly $\mathrm{Mg}_{2} \mathrm{Si}$. More recent works [20-22] report a peak around $250^{\circ} \mathrm{C}$ as the growth of the quaternary (Q' or $\lambda^{\prime}$ )-AlCuMgSi phase and a peak around $280^{\circ} \mathrm{C}$ as the apparition of the $\theta^{\prime}-\mathrm{Al}_{2} \mathrm{Cu}$ phase. The fifth region (V) is a small exothermic peak between $350^{\circ} \mathrm{C}$ and $400{ }^{\circ} \mathrm{C}$, associated by some authors to the incoherent $\theta-\mathrm{Al}_{2} \mathrm{Cu}$ phase precipitation [22]. However, instead of a precipitation peak, this shoulder could correspond to the start of the dissolution of precipitates present in the alloy, which occurs here between $450{ }^{\circ} \mathrm{C}$ and $520^{\circ} \mathrm{C}$ (region VI) and then proceeds to full solid solution at the solutionizing temperature.

The main observation from Fig. 1 is the similarity in between the A-U4G and 2017A behaviour. In the measurements, the observed peaks are close to what is reported for the Duralumin in 1952 by Saulnier and Syre [7] and for the 2017A alloy by Härtel et al. [14]. Similar precipitation should thus be expected. Peak V is however slightly shifted to higher temperatures (around $400^{\circ} \mathrm{C}$ ) for 2017A compared with A-U4G (around $350{ }^{\circ} \mathrm{C}$ ). This could be the sign of an earlier start for precipitate dissolution in the A-U4G alloy.

Representative bright-field TEM images in conventional mode for the as-received samples oriented in [001] $]_{\mathrm{Al}}$ zone axis are shown in Fig. 2(a) and (b). In the as-received samples, only dispersoids (AlMnSi) can be observed in bright field mode: they are larger in size $(125 \mathrm{~nm} \pm 51 \mathrm{~nm}$ in average) in 2017A than in the A-U4G $(57 \mathrm{~nm} \pm 25 \mathrm{~nm}$ in average), both presenting a large standard deviation. Diffraction patterns (not shown in Fig. 2) do not present any visible spot that can be attributed to coherent precipitation.

Atomic resolved STEM-HAADF experiments were performed on the as-received alloys, see Fig. 3 for the images of A-U4G in $[001]_{\mathrm{Al}}$ zone axis. Precipitation in the matrix was hardly detectable. In HAADF-mode, see Fig. 3(b) and (d), the intensity is proportional to $\mathrm{Z}^{1.5-1.8}$, $\mathrm{Z}$ being the atomic number [23]. Bright dots/areas correspond to the heavier element and are thus representative of copper atoms. The EDS analysis confirmed the presence of copper in higher concentration in these zones compared with the matrix. Thus, Cu-rich zones, not very well defined and having a size of a few nanometres, were detected here and there in the matrix (see Fig. 3(a) and (b)). Some clusters were also located at the matrix/dispersoid interfaces (see Fig. 3(c) and (d)).

SAXS measurements, performed on A-U4G and 2017A alloys in the as-received state, are shown in Fig. 4. The SAXS data observed on both specimens show a very similar behaviour that can be described by two main contributions. In the low $q$-range $\left(0.01<q<0.1 \AA^{-1}\right)$, a clear $q^{-4}$ contribution is observed, which can be attributed to large precipitates such as the dispersoids. In the range $0.1<q<1 \AA^{-1}$, a plateau is observed, followed by an intensity decrease as q increases. We have modelled this contribution by a distribution of spherical precipitates of uniform electron density (i.e., composition) with a polydispersity given by the Schultz distribution (see [24] for the detailed expression of this contribution). A least-square fit of the data gives mean diameters of about $8 \AA$, which is consistent with the existence of GPZ or small clusters in the alloy matrix. The exact nature of the clusters is at this stage not determined.

\subsection{Artificial aging treatment at $180^{\circ} \mathrm{C}$ and identification of precipitates}

Fig. 5 presents the Vickers hardness as a function of aging time for the two studied alloys: A-U4G and 2017A. Only RP hardness was plotted as measurements on other planes gave similar results. The A-U4G is harder than the modern alloy 2017A by about $10 \mathrm{HV}$ throughout the aging curve except for long over-aging times where the A-U4G hardness drops faster. In both cases, the conditions corresponding to the maximum peak hardness were reached after $8 \mathrm{~h}$ at $180^{\circ} \mathrm{C}$. These peak ageing conditions were selected for the investigation of the microstructure.

Fig. 6 shows the SAXS measurements after aging for $8 \mathrm{~h}$ at $180^{\circ} \mathrm{C}$. Once again, both alloys behave similarly. From these measurements, it is seen that the signal, in the range of $0.1<q<1 \AA^{-1}$, disappeared in favour of a signal in the range $0.04<q<0.2 \AA^{-1}$, which translates into the disappearance of small clusters and the formation of larger particles. This contribution to the scattered intensity can be reproduced by using a flat cylinder model. Dimensions of precipitates are: $4 \mathrm{~nm}$ thick and $70 \mathrm{~nm}$ long for A-U4G and $3 \mathrm{~nm}$ thick and $40 \mathrm{~nm}$ long for 2017A.

The microstructures corresponding to this peak-aged condition in both alloys, observed by TEM in conventional mode are shown in 

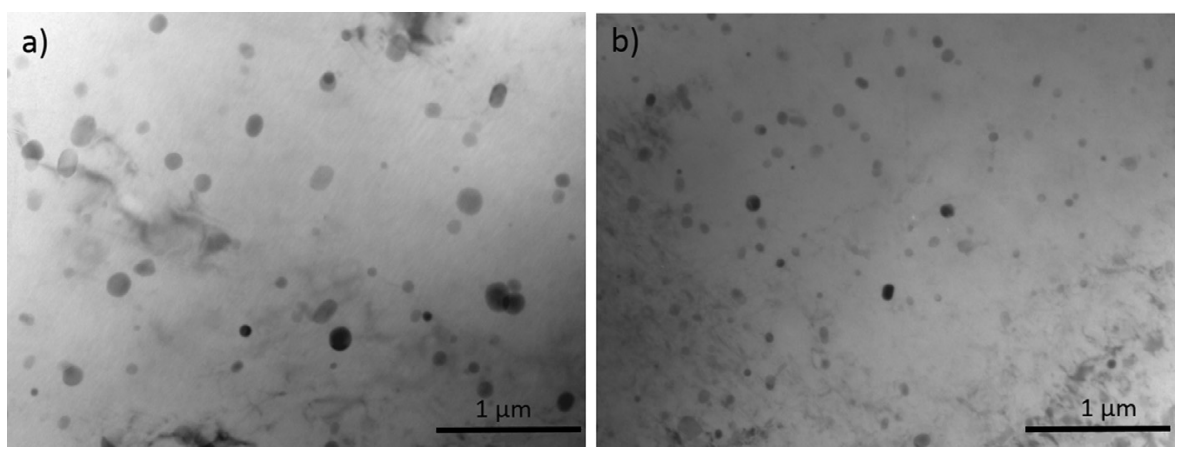

Fig. 2. TEM bright field images of as-received alloys (a) 2017A ; (b) A-U4G showing mainly AlMnSidispersoids in the matrix.
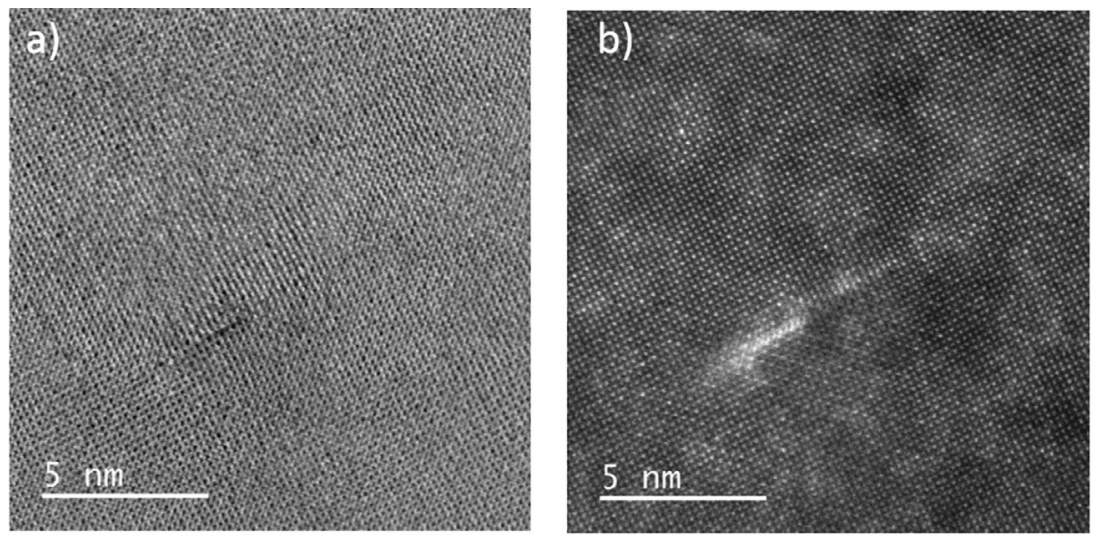

Fig. 3. STEM images of as-received A-U4G alloy in $[001]_{\mathrm{Al}}$ zone axis; (a) and (c) Annular bright field; (b) and (d) high angle annular dark field. Images (a) and (b) on one side and (c) and (d) on the other side correspond to the exact same area. A cluster is indicated with the white arrow at the interface dispersoid/matrix.
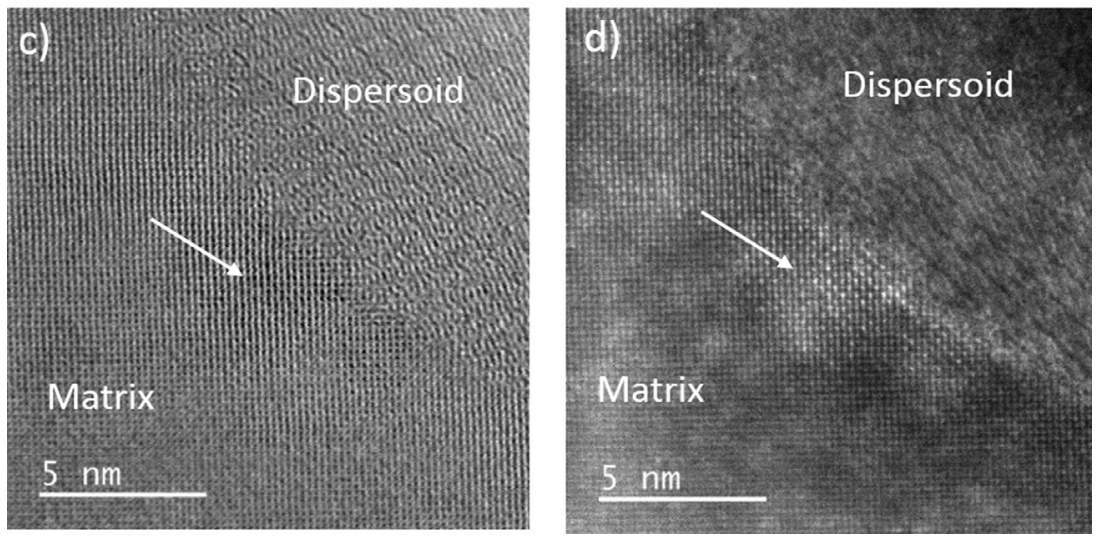

Fig. 7: bright-field images and corresponding selected-area electron diffraction patterns are presented. Fig. 8 shows the STEM-EDS mapping for the A-U4G alloy.

After $8 \mathrm{~h}$ at $180^{\circ} \mathrm{C}$, a very dense precipitation is observed inside the matrix (Fig. 7) and at grain boundaries (Fig. 8). In both alloys (Fig. 7(a) and (c)), precipitates lying in $\{100\}_{\mathrm{Al}}$ planes are observed: some as platelets and others as rods, with precipitation on dislocations. As the observed precipitation is similar in both A-U4G and 2017A alloys, advanced analyses results are then only shown for A-U4G alloy.

In Fig. 8, precipitates at grain boundaries were identified by EDS: they are (Mg, Si)-precipitates and copper precipitates. On these EDS maps, dispersoids of AlMnSi nature are present. A precipitation in the matrix is also visible but hardly identifiable.

As a matter of fact, different precipitates populations co-exist inside the grains and their identification was made possible by combining different electron microscopy techniques. From SADP taken along $[001]_{\mathrm{Al}}$ zone axis, shown in Fig. 7(b) and (d), the presence of $\theta^{\prime}-\mathrm{Al}_{2} \mathrm{Cu}$ phase was evidenced thanks to the strikes along $\langle 001\rangle_{\mathrm{Al}}$ directions and faint spots $(110)_{\theta}$, at $\frac{1}{2}$ of $(220)_{\mathrm{Al}}$ [25]. They correspond to three vari- ants of plate-shape semi-coherent precipitates growing in the $\{100\}_{\mathrm{Al}}$ planes: one face-on and two edge-on. The $\theta^{\prime}-\mathrm{Al}_{2} \mathrm{Cu}$ precipitate nature was confirmed thanks to STEM-HAADF as shown in Fig. 9(b). Similarly to HAADF images taken on as-received states, bright dots correspond to copper-rich atomic columns. Seen edge-on, the crystal structure of this platelet is body-centred tetragonal as previously shown by Bourgeois et al. [26] and Shen et al. [27]. The presence of pre- $\theta$ '-1 $\left(\mathrm{Al}_{2} \mathrm{Cu}\right)$ precipitates coherent on the $\{100\}_{\mathrm{Al}}$ planes, was also revealed with STEMHAADF, as shown in Fig. 9(c)): these types of precipitates were recently identified by Liu et al. [28]. They consist of three parallel copper planes, each separated by two aluminium planes. On SADP, diffraction patterns of the pre- $\theta^{\prime}-1$ coincide with diffraction patterns of $\theta^{\prime}-\mathrm{Al}_{2} \mathrm{Cu}$. Both types are thus, difficult to differentiate. At peak-aged conditions, this phase, which corresponds to the first stage of $\theta^{\prime}-\mathrm{Al}_{2} \mathrm{Cu}$ formation, is not predominant: most of the population has evolved to the $\theta^{\prime}-\mathrm{Al}_{2} \mathrm{Cu}$ phase.

Other precipitates in the shape of rods were observed in the A-U4G alloy after $8 \mathrm{~h}$ at $180^{\circ} \mathrm{C}$, as shown in the bright field images of Fig. 7(a) and in the HAADF image of Fig. 9(a). The rods, seen end-on, are oriented along $\langle 001\rangle_{\mathrm{Al}}$ directions. No clear identification being possible with 


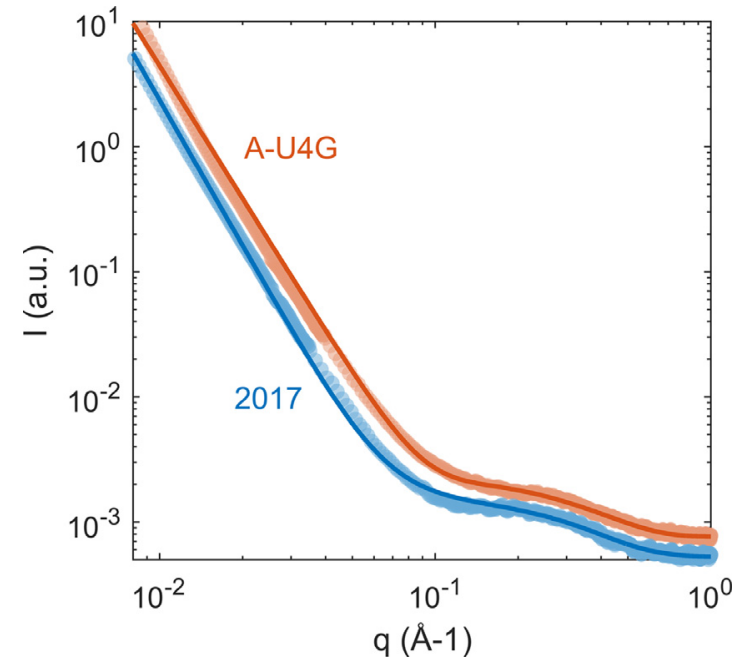

Fig. 4. SAXS curves for 2017A and A-U4G in the as-received state. The model was superimposed to the experimental curves.

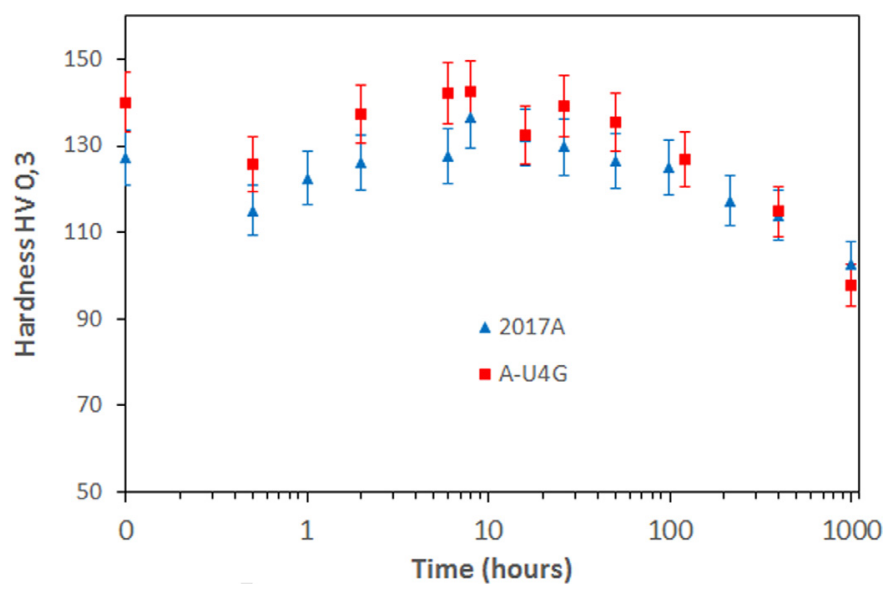

Fig. 5. Hardness measurement on rolling plane for old (A-U4G) and modern (2017A) alloys heat treated at $180^{\circ} \mathrm{C}$.

SADP, this phase was identified thanks to STEM-EELS. Rods appeared to be the Q-AlCuMgSi phase or one of its precursors (Q'). The composition found for this phase by STEM-EELS was in average $73 \pm 10 \mathrm{Al}-10 \pm 4$ $\mathrm{Cu}-12 \pm 6 \mathrm{Mg}-5 \pm 5 \mathrm{Si}$ at $\%$. Aluminium content for this phase is overestimated as part of the matrix is also probed. Moreover, as observed on the STEM-HAADF image (Fig. 10(b)) and confirmed by STEM-EELS, the precipitates have a core-shell structure with a core rich in silicon and magnesium and a copper-rich shell. This core-shell structure observed here coincides with results reported by Matsuda et al. in 2007 [29] and Biswas et al. in 2014 [21].

In Fig. 9(b), one of the quaternary precipitate is seen edge-on, coprecipitated with a $\theta^{\prime}-\mathrm{Al}_{2} \mathrm{Cu}$ precipitate. In this orientation, by STEMHAADF, the Q'(Q)-AlCuMgsi phase can be recognized by the Cu-rich columns (high intensity due to high atomic number) surrounded by lower intensity columns ( $\mathrm{Si}, \mathrm{Al}$ and $\mathrm{Mg}$ ) similar to the cross-section structure viewed along $\langle 100\rangle_{\mathrm{Al}}$ zone axis shown in Ding et al. [30].

Eventually, a third phase is present, detected thanks to the spots at $1 / 3$ and $2 / 3$ of the $[022]_{\mathrm{Al}}$ orientation in SADP (Fig. 7(b) and (d)). STEM-HAADF in two orientations $[110]_{\mathrm{Al}}$ and $[112]_{\mathrm{Al}}$ (see Fig. 11) was necessary to identify this phase as the $\Omega-\mathrm{Al}_{2} \mathrm{Cu}$. This phase is known to have an orthorhombic structure, space group Fmmm with $a=0.496 \mathrm{~nm}$; $b=0.859 \mathrm{~nm}$ and $c=0.848 \mathrm{~nm}$ and to precipitate in the $\{111\}_{\mathrm{Al}}$ planes [31]. Measurements of $\mathrm{Cu}-\mathrm{Cu}$ distances on STEM-HAADF images along

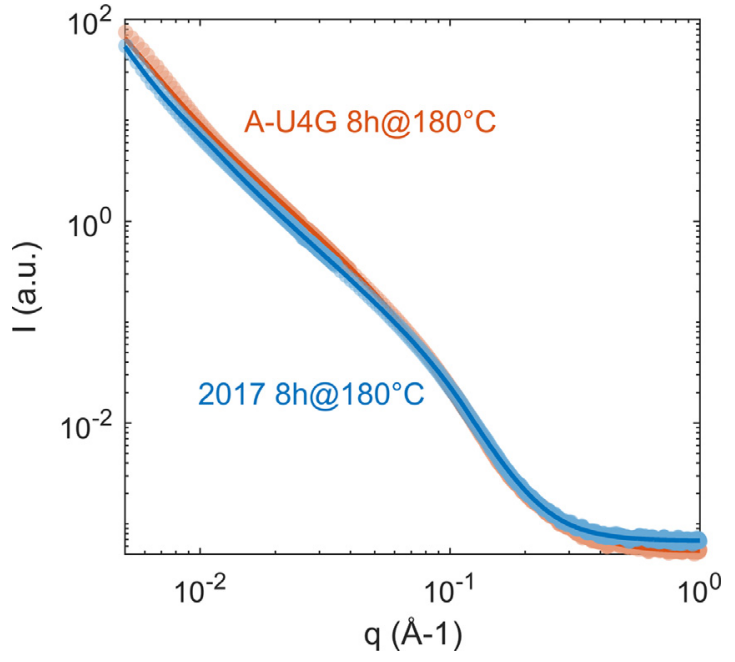

Fig. 6. SAXS curves for 2017A and A-U4G at peak-aging state: after $8 \mathrm{~h}$ at $180^{\circ} \mathrm{C}$. The model was superimposed to the experimental curves.

$[001]_{\Omega},[100]_{\Omega}$ and $[010]_{\Omega}$ correlate with the expected lattice parameters. These precipitates grow preferentially on dispersoids (AlMnSi).

All the observations provided a clear evidence on the phases present upon artificial aging: at grain boundaries, copper and $\mathrm{Mg}$-Si precipitates were formed while in the matrix, $\theta^{\prime}-\mathrm{Al}_{2} \mathrm{Cu}, \mathrm{Q}^{\prime}(\mathrm{Q})-\mathrm{AlCuMgSi}$ and $\Omega-\mathrm{Al}_{2} \mathrm{Cu}$ were clearly identified.

\section{Discussion}

\subsection{Hardness evolution}

The higher hardness of A-U4G compared to 2017A in the as-received state (about $10 \mathrm{HV}$ difference) could be explained by different factors. When considering precipitation at nanoscale, SAXS experiments provided evidence of the presence of clusters in as-received state whether in A-U4G or in 2017A. DSC confirmed the presence of this population in the as-received state, as a dissolution event occurred around $180^{\circ} \mathrm{C}$. These clusters, with a diameter in the range of $8 \AA$, are the principal cause of hardness in Duralumin. However, it was shown that the nanoprecipitation is identical in both alloys, which rules out this factor as the primary cause in the hardness difference. Secondly, dispersoids contribute partly to hardness by controlling the grain size. It was shown that they are smaller and more numerous in A-U4G than in 2017A. This could be an explanation for the difference in hardness. However, since the grain size is close in both alloys (see Fig. S2 in Supplementary information), the contribution of dispersoids should not be significant. The third explanation comes from the plates' conditions. The old plate was bent when collected. This action generated strain hardening, with a higher density of dislocations (see Fig. S3 in Supplementary information). The presence of these dislocations is believed to be the main factor in the higher hardness of the A-U4G alloy in the as-received state.

For over-ageing conditions, the hardness of the A-U4G alloy drops faster until reaching the hardness of the modern alloy. It can be hypothesized that after artificial ageing, the historical alloy loses part of its additional dislocation density through faster recovery. The final part of the hardness curve could also be explained be the fact that alloys age faster when additional dislocations are introduced, because the dislocation network transports solute atoms through pipe diffusion [32] and thus accelerates growth and coarsening of $\theta$ ' precipitates, known to nucleate on dislocations [33]. This growth and coarsening will induce a decrease in hardness. 

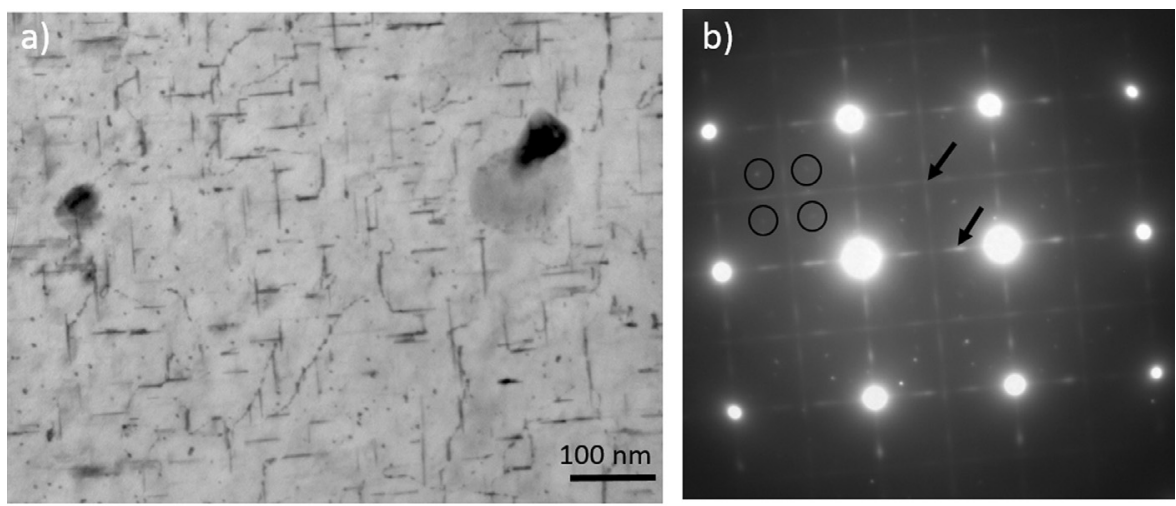

Fig. 7. TEM bright-field images and corresponding SADP in $[001]_{\mathrm{Al}}$ zone axis after treatment at $180^{\circ} \mathrm{C}$ $8 \mathrm{~h}$ for 2017A: (a) and (b) and for A-U4G: (c) and (d). $(110)_{\theta}$, spots and strikes along $[001]_{\mathrm{Al}}$ directions for the $\theta$ ' phase are indicated with arrows. Spots at $1 / 3$ and $2 / 3$ of $(022)_{\mathrm{Al}}$ corresponding to $\Omega$ phase are surrounded.
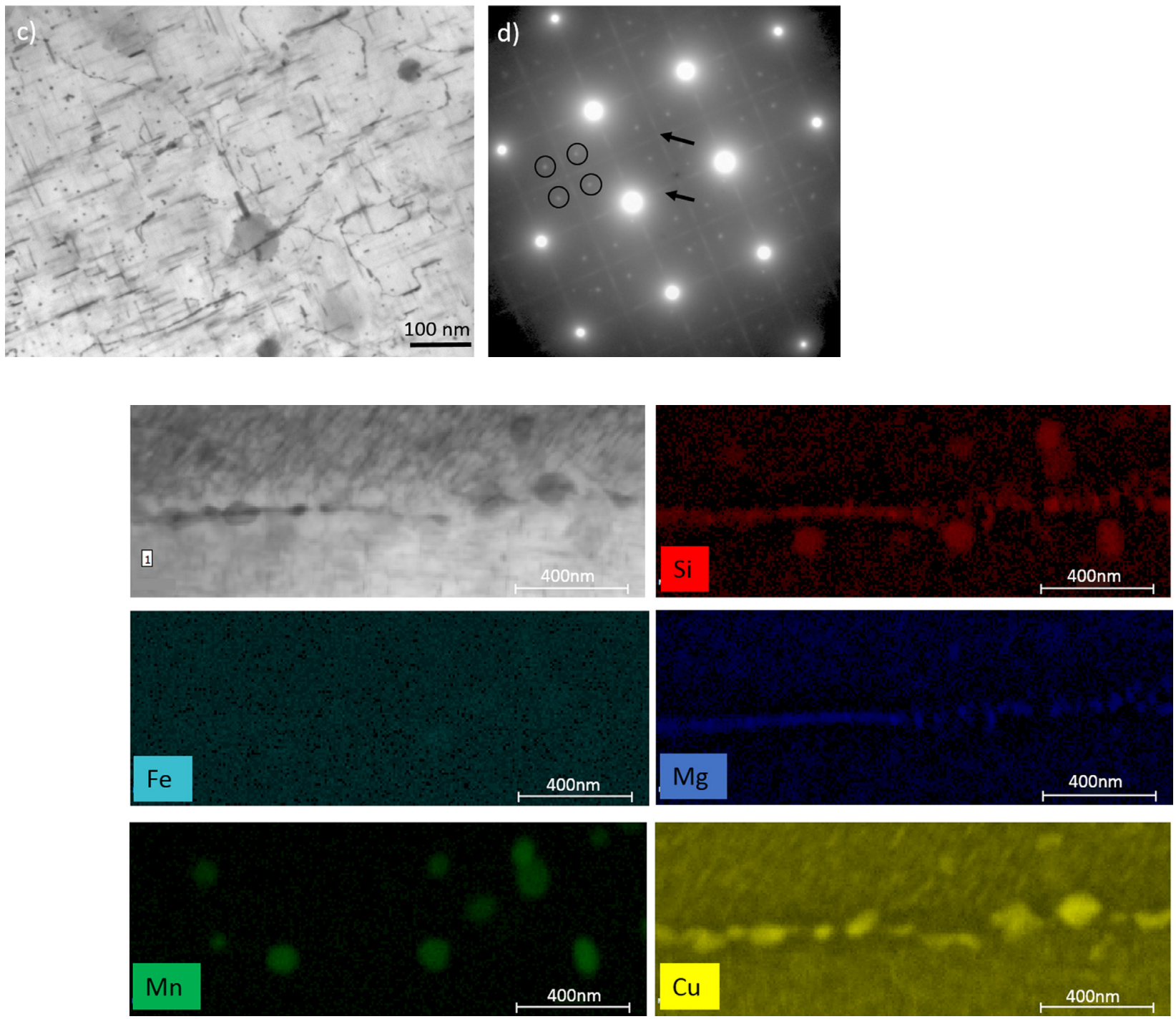

Fig. 8. STEM-EDS mapping after treatment at $180^{\circ} \mathrm{C}-8 \mathrm{~h}$ in A-U4G showing precipitation at grain boundaries: $\mathrm{MgSi}$ and $\mathrm{Cu}$ as well as in the matrix.

\subsection{Nano-structure in the as-received state}

About the nano-clusters present in the as-received states, several points can be made. The copper-rich clusters observed by atomicallyresolved TEM images in HAADF mode were not sufficiently numerous to correlate with the measured SAXS signal. Electron microscopy is thus not fully succeeding in observing and analysing nanoclusters. On another hand, at this stage, our experiments cannot differentiate between GPZ (flat clusters growing in the planes parallel to the $\langle 100\rangle_{\mathrm{Al}}$ axes) and disordered clusters. GPZ are usually found in the model $\mathrm{Al}-4 \% \mathrm{Cu}$ alloy aged at room-temperature, as it was firstly proved by Guinier and Preston by XRD in 1938. Lambot [11], who studied both Al-4\%Cu and Duralumin by X-ray scattering, proved that the scattering signal was perfectly identical in both alloys, concluding thus that GP zones are present in Duralumin aged at room temperature. It is to be noted that their studies were carried out on single crystals. In the present case, SAXS signal is an average of the measurements made on several grains: the information related to orientation and/or anisotropy is then cancelled out. 

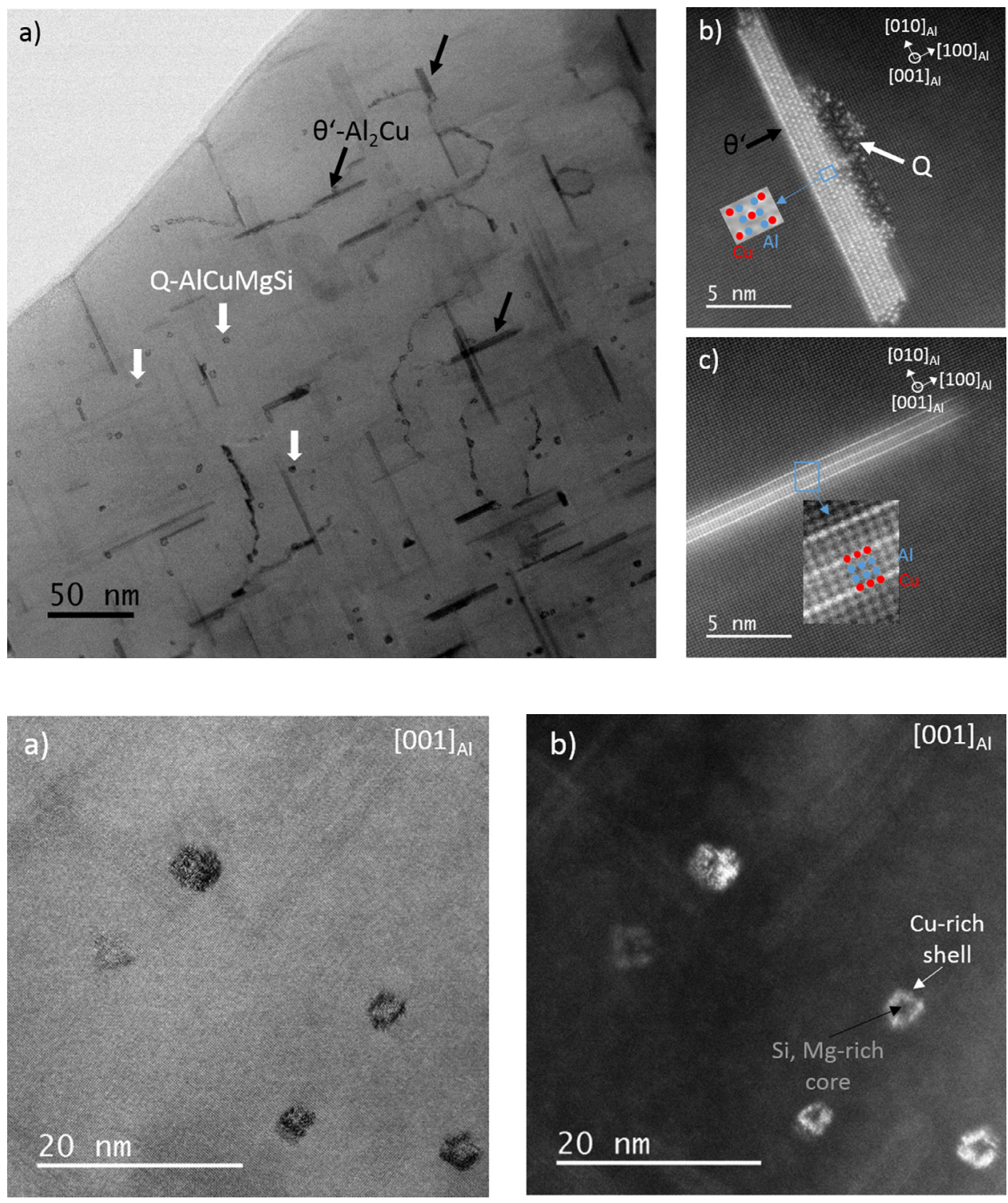

Fig. 9. (a) STEM Bright-field image of $A-U 4 G$ alloy in $[001]_{\mathrm{Al}}$ zone axis showing $\theta^{\prime}-\mathrm{Al}_{2} \mathrm{Cu}$ (black arrows) and Q-AlCuMgSi rods (white arrows), (b) HAADF images of $\theta^{\prime}-\mathrm{Al}_{2} \mathrm{Cu}$ platelets seen edge-on with co-precipitation of $\mathrm{Q}^{\prime}(\mathrm{Q})$ $\mathrm{AlCuMgSi}$ and (c) pre- $\theta^{\prime}-1 \mathrm{Al}_{2} \mathrm{Cu}$ disks seen edge-on.
Further investigation is required to confirm the structural nature of these clusters.

\subsection{Upon artificial aging - identification of precipitation}

Upon artificial aging (at $180^{\circ} \mathrm{C}$ for $8 \mathrm{~h}$ ), it was demonstrated that three populations of precipitates coexist in the matrix: $\theta^{\prime}-\mathrm{Al}_{2} \mathrm{Cu}, \mathrm{Q}^{\prime}(\mathrm{Q})$ $\mathrm{AlCuMgSi}$ and $\Omega-\mathrm{Al}_{2} \mathrm{Cu}$. Linking back the TEM observations with DSC results and thanks to results reported in the literature for $\mathrm{Al}-\mathrm{Cu}-\mathrm{Mg}-$ $\mathrm{Si}$ alloys, it can be hypothesized that region III (between $220^{\circ} \mathrm{C}$ and $280^{\circ} \mathrm{C}$ ) is related to the growth of Q'(Q)-AlCuMgSi phase and region IV (between $280^{\circ} \mathrm{C}$ and $320^{\circ} \mathrm{C}$ ) to the growth of the $\theta^{\prime}-\mathrm{Al}_{2} \mathrm{Cu}$ phase. As for the $\Omega-\mathrm{Al}_{2} \mathrm{Cu}$ phase, having the same stoichiometry as the $\theta^{\prime}-\mathrm{Al}_{2} \mathrm{Cu}$ phase and if its growth is controlled by diffusion, there could be superimposition of peaks in the DSC curve.

The $\theta^{\prime}-\mathrm{Al}_{2} \mathrm{Cu}$ phase, found in large quantity, is not surprising. It constitutes the main hardening phase in the $2 \mathrm{xxx}$ family alloys and was reported in all studies on Duralumin or 2017A alloy [7,11,13].

The presence of the Q-AlCuMgSi phase or one of his precursors (Q') was evidenced, in both old and modern alloys. Although not systematically revealed in previous studies of Duralumin, these findings confirm the equilibrium diagrams data reported by Mondolfo in 1943
[12] which predicts that with $\mathrm{Mg}$ :Si ratio $<1.73$, hardening constituents should lead to the $\mathrm{Al}_{2} \mathrm{Cu}$ and $\mathrm{Al}_{4} \mathrm{CuMg}_{5} \mathrm{Si}_{4}$ equilibrium phases. The silicon content is indeed higher than that required for the formation of $\mathrm{Mg}_{2} \mathrm{Si}(\mathrm{Mg}: \mathrm{Si}=1.08)$ : the excess of silicon will combine with copper and magnesium to form the quaternary phase. The global stoichiometric composition for the $\mathrm{Q}$ phase has been, however, a controversial matter. Mondolfo predicts two possible quaternary phases: $\mathrm{Al}_{4} \mathrm{CuMg}_{5} \mathrm{Si}_{4}$ or $\mathrm{Al}_{4} \mathrm{CuMg}_{4} \mathrm{Si}_{4}$. In more recent literature, mainly for alloys of the $6 \mathrm{xxx}$ family (Al-Mg-Si with additions of copper) [15], but also for 2014 alloys [20], the stoichiometry reported in bulk alloys were $\mathrm{Al}_{5} \mathrm{Cu}_{2} \mathrm{Mg}_{8} \mathrm{Si}_{6}$, $\mathrm{Al}_{4} \mathrm{Cu}_{2} \mathrm{Mg}_{8} \mathrm{Si}_{7}, \mathrm{Al}_{3} \mathrm{Cu}_{2} \mathrm{Mg}_{9} \mathrm{Si}_{7}$ etc. However, the nanometre scale of these precipitates makes the quantitative analyses challenging. Biswas et al. [21] used atom probe analysis and proved that the $\mathrm{Q}$ precipitates evolved, upon aging, from a copper-rich composition (44Al-22Cu$16 \mathrm{Mg}-16,5 \mathrm{Si}$ at $\%$ ) to a magnesium and silicon-rich composition (28Al$9 \mathrm{Cu}-37 \mathrm{Mg}-26 \mathrm{Si}$ at\%.) after $4 \mathrm{~h}$ at $260^{\circ} \mathrm{C}$. In a very recent paper, Ding et al. [30] were able to provide, by combining atom probe tomography and atomic column intensity quantification in STEM-HAADF images, the reason why varying composition were reported in past work: it was indeed proved to be due to the occupancy change of the atomic columns. The stoichiometry of the $Q$ phase and its precursor, the $Q^{\prime}$ phase were found to be: $\mathrm{Al}_{5} \mathrm{Cu}_{3} \mathrm{Si}_{6} \mathrm{Mg}_{9}$ and $\mathrm{Al}_{12} \mathrm{Cu}_{1} \mathrm{Si}_{4} \mathrm{Mg}_{5}$, respectively. Even if 

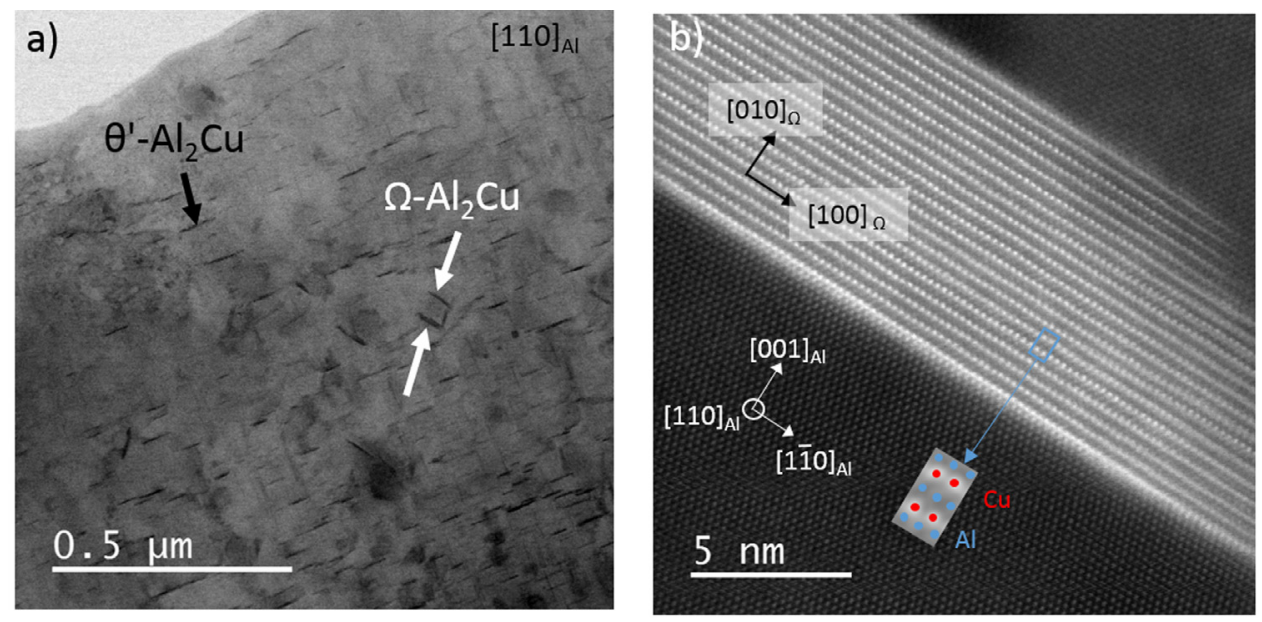

Fig. 11. STEM Bright-field images and HAADF images of A-U4G alloy in (a) and (b): $[110]_{\mathrm{Al}}$ zone axis; (c) and (d): $[11 \overline{1} 2]_{\mathrm{Al}}$ zone axis showing $\Omega-\mathrm{Al}_{2} \mathrm{Cu}$ platelets (white arrows) growing on dispersoids.
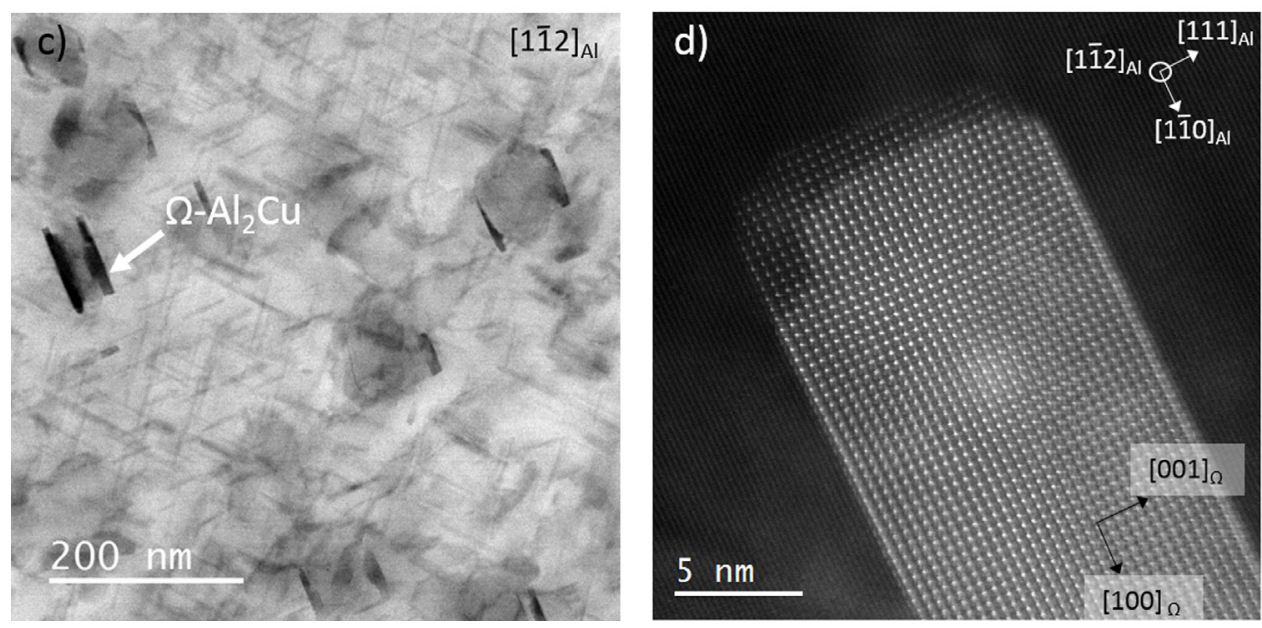

matrix effects cannot be excluded with EELS, the elemental composition found here by EELS in Duralumin $(73 \pm 10 \mathrm{Al}-10 \pm 4 \mathrm{Cu}-12 \pm 6 \mathrm{Mg}-$ $5 \pm 5 \mathrm{Si}$ at $\%$ ) is in all cases much leaner in magnesium and silicon than what is usually reported. This results should be corroborated with other techniques to confirm the tendency. The heterogeneous nucleation of $\theta^{\prime}-\mathrm{Al}_{2} \mathrm{Cu}$ phase and the $\mathrm{Q}^{\prime}(\mathrm{Q})-\mathrm{AlCuMgSi}$ phase, observed in Fig. 9(b), was also reported by other authors $[21,34]$. It could be caused by the strain field of Q-phase precipitates on which the $\theta^{\prime}-\mathrm{Al}_{2} \mathrm{Cu}$ nucleate.

Another phase, $\Omega-\mathrm{Al}_{2} \mathrm{Cu}$, is here observed. The $\Omega$ phase is usually found in high density in Al-Cu-Mg-Ag quaternary alloys with a high $\mathrm{Cu}: \mathrm{Mg}$ ratio $[25,31]$. It presents one of the highest strengthening potential in aluminium alloys. In particular, $\mathrm{Al}-\mathrm{Cu}-\mathrm{Mg}-\mathrm{Ag}$ alloys have been developed for elevated temperature aerospace industry applications [35] due to the enhanced thermal stability of the $\Omega$ phase. Some authors proved that silver was not required for the formation of $\Omega$ precipitates although its presence increases their density [36]. The $\Omega$ phase was indeed observed in 2024 and 2124 alloys by Wang et al. [37] and was actually found in 2017A alloy as well [14]. In 2024 and 2014 alloys, the $\Omega$ phase was found to form preferentially on manganese-based dispersoids. This heterogeneous growth is clearly evidenced in our reported results. To understand why such a phase appeared in Duralumin, it is interesting to discuss its nucleation process. In $\mathrm{Al}-\mathrm{Cu}-\mathrm{Mg}-\mathrm{Ag}$ alloys, the process has been widely investigated: upon aging, magnesium and silver co-cluster, then copper atoms aggregate to the $\{111\}_{\mathrm{Al}}$ planes. During coarsening, when copper concentration becomes close to $\mathrm{Al}_{2} \mathrm{Cu}$, silver and magnesium start to migrate from the interior to the interface of the precipitate. The interfacial structure was proved to be a doublelayer composed of $\mathrm{Ag}$ in hexagonal structure and $\mathrm{Mg}$ and $\mathrm{Cu}$ below the centre of the hexagon [38]. Magnesium is considered necessary for the nucleation of the $\Omega$ phase. As for silver, its role is to accelerate the aggregation of magnesium atoms by retaining vacancies and to assist in this way the magnesium diffusion [39]. Silicon is also an element that influences the presence of $\Omega$ phase. From Polmear et al. [35], silicon (and iron) should remain low (less than $0.10 \mathrm{wt} \%$ ) to minimise the formation of low melting point eutectics at grain boundaries and to maximise $\Omega$ precipitation. In fact, high levels of silicon interfere with precipitation of $\Omega$ because silicon interacts with magnesium and thus reduces the formation $\mathrm{Mg}-\mathrm{Ag}$ co-clusters, which generally facilitate nucleation of $\Omega$. This was also observed in the work by Ünlu et al. [40]. However, the authors showed that it is rather the Mg:Si ratio that had to be considered: some $\Omega$ precipitation was found in alloys with silicon levels as high as 0.5 and $0.65 \mathrm{wt} \%$ with corresponding $\mathrm{Mg}: \mathrm{Si}$ ratios of 3.0 and 2.23. In the present alloys, the observation that $\Omega$ forms principally on dispersoids in the Duralumin and 2017A can be explained by the presence of copper clusters at the matrix/dispersoid interface in the as-received state. Moreover, it does not form as a phase dispersed in the matrix because of the absence or the very low density of magnesium clusters in the matrix. The magnesium clusters are in this case impeded by silicon, which rather facilitates the formation of the Q-AlCuMgSi phase.

\section{Conclusion}

An old Duralumin (A-U4G) and its modern equivalent (2017A) were studied with different characterization techniques to clarify the precipitation processes. The main findings are:

- The precipitation sequence in Duralumin and modern 2017A upon artificial aging is similar. It consists in $\theta^{\prime}-\mathrm{Al}_{2} \mathrm{Cu}, \mathrm{Q}^{\prime}(\mathrm{Q})-\mathrm{AlCuMgSi}$ and $\Omega-\mathrm{Al}_{2} \mathrm{Cu}$ in the matrix. At grain boundaries, various precipitates 
are found: copper-based and $(\mathrm{Mg}, \mathrm{Si})$ precipitates with unknown stoichiometry.

- The Q-AlCuMgSi phase or one of its precursors (Q') is observed in the matrix but the $\beta-\mathrm{Mg}_{2} \mathrm{Si}$ phase, previously reported in Duralumin, is not present. This phase facilitates the nucleation of the $\theta^{\prime}-\mathrm{Al}_{2} \mathrm{Cu}$ phase through strain field.

- The $\Omega$ phase is observed and it grows preferentially on dispersoids. It presumably nucleates due to the presence of copper clusters at the matrix/dispersoid interface. This phase is a minor phase due to the absence or rare occurrence of magnesium clusters in the matrix. The nucleation mechanisms for the $\Omega$ phase on dispersoids in these $\mathrm{Al}-\mathrm{Cu}-\mathrm{Mg}-\mathrm{Si}$ alloys remains to be evidenced.

- In the as-received state (naturally aged), the presence of clusters is evidenced, with copper as the main element but the structural nature of these clusters is yet to be determined.

- Despite some differences in the microstructure, such as the dispersoids' size and density, Duralumin exhibits a similar nanoprecipitation as its modern equivalent in the naturally aged conditions, and it behaves also similarly upon artificial aging. These observations lead to the conclusion that the conditions experienced by the collected plate (10 years of service plus 50 years at ambient temperature) had no significant impact on the nanostructure.

Overall, these results constitute a base for assessing the very longterm aging of aluminium alloys in aeronautics.

\section{Declaration of Competing Interest}

None

\section{Acknowledgments}

The authors which to thank Pierre Roblin from FR FERMAT, Université de Toulouse, CNRS, Toulouse, France, for SAXS measurements, Teresa Hungria-Hernandez, from Raimond Castaing Microanalysis Centre, Toulouse for STEM (HAADF, EDS and EELS) experiments and the volunteers of Les Ailes Anciennes Toulouse for providing us with the plate collected on the Breguet Sahara 765 aircraft.

This study has been partially supported through the grant NanoX $n^{\circ}$ ANR-17-EURE-0009 in the framework of the "Programme des Investissements d'Avenir".

\section{Supplementary material}

Supplementary material associated with this article can be found, in the online version, at doi:10.1016/j.mtla.2019.100429.

\section{References}

[1] O. Hardouin Duparc, Alfred Wilm et les débuts de Duralumin, Cah. d'hist. de l'alum. Inst. Pour l'Hist. de l'Alum. Paris (2005) 63-77.

[2] M. Victor, Comment a été construit le premier avion en Duralumin, Rev. Alum. (1951) 339-340.

[3] P.D. Merica, R.G. Waltenberg, H. Scott, Heat treatment of Duralumin, Sci. Pap. Bur. Stand. 15 (1919) 271-316 Scientific Paper 347 (S347).

[4] E. Orowan, Zur kristallplastizität. III, Z. Phys. 89 (9) (1934) 634-659.

[5] A. Guinier, Structure of age-hardened aluminium-copper alloys, Nature 142 (1938) 569.

[6] G.D. Preston, LXXIV. The diffraction of X-rays by an age-hardening alloy of aluminium and copper. The structure of an intermediate phase. The London, Edinburgh, and Dublin, Philos. Mag. J. Sci. 26 (178) (1938) 855-871.

[7] A. Saulnier, R. Syre, Maturation, revenu et réversion des alliages Al-Cu 4\%, Al-Cu-Mg et Al-Cu-Mg-Si de haute pureté, Rev. Met. Paris 49 (1) (1952) 1-21.

[8] Duralumin, notice générale, Société du Duralumin, Paris, 1938.
[9] H. Lebouteux, La symbolisation de l'aluminium et de ses alliages en France et dans quelques pays étrangers, Encycl. Trav. Alum. Extrait Rev. Alum. Paris (1956) 1-3.

[10] The-Aluminum-Association, International alloy designations and chemical composition limits for wrought aluminum and wrought aluminum alloys, 2015 http://www.aluminum.org/resources/industry-standards/aluminum-alloys-101.

[11] H. Lambot, Etude cristallographique de la précipitation structurale dans les duralumins, Rev. Met. Paris 47 (10) (1950) 709-726.

[12] L.F. Mondolfo, Metallography of Aluminum Alloys, John Wiley \& Sons, Inc., New York, USA, 1943.

[13] S. Yano, S. Koda, Electron microscope observation of duralumin, J. Jpn. Inst. Light Metals 18 (7) (1968) 371-376.

[14] M. Härtel, S. Wagner, P. Frint, M.F.-X. Wagner, Effects of particle reinforcement and ecap on the precipitation kinetics of an Al-Cu alloy, IOP Conf. Ser.: Mater. Sci. Eng. 63 (1) (2014) 012080.

[15] D.G. Eskin, Decomposition of supersaturated solid solutions in $\mathrm{Al}-\mathrm{Cu}-\mathrm{Mg}-\mathrm{Si}$ alloys, J. Mater. Sci. 38 (2) (2003) 279-290.

[16] J.-F. Nie, 20 - Physical metallurgy of light alloys, in: D.E. Laughlin, K. Hono (Eds.), Physical Metallurgy, 5th Edition, Elsevier, Oxford, 2014, pp. 2009-2156.

[17] R. Develay, Propriétés de l'aluminium et des alliages d'aluminium corroyés, Tech. de l'Ing. M440 - V2 (1992).

[18] Breguet, Standard forms, Vélizy factory, Archives Les Ailes Anciennes Toulouse, 1946-1954.

[19] A. Deschamps, F. de Geuser, Quantitative characterization of precipitate microstructures in metallic alloys using small-angle scattering, Metall. Mater. Trans. A 44 (1) (2013) 77-86.

[20] I. Dutta, C.P. Harper, G. Dutta, Role of $\mathrm{Al}_{2} \mathrm{O}_{3}$ particulate reinforcements on precipitation in 2014 Al-matrix composites, Metall. Mater. Trans. A 25 (8) (1994) 1591-1602.

[21] A. Biswas, D.J. Siegel, D.N. Seidman, Compositional evolution of Q-phase precipitates in an aluminum alloy, Acta Mater. 75 (Suppl. C) (2014) S322-S336.

[22] P. Bassani, E. Gariboldi, D. Ripamonti, Thermal analysis of Al-Cu-Mg-Si alloy with Ag/Zr additions, J. Therm. Anal. Calorim. 91 (1) (2008) 29-35.

[23] S.J. Pennycook, Z-contrast stem for materials science, Ultramicroscopy 30 (1) (1989) 58-69.

[24] M. Kotlarchyk, S.H. Chen, Analysis of small angle neutron scattering spectra from polydisperse interacting colloids, J. Chem. Phys. 79 (5) (1983) 2461-2469.

[25] S.C. Wang, M.J. Starink, Precipitates and intermetallic phases in precipitation hardening Al-Cu-Mg-(Li) based alloys, Int. Mater. Rev. 50 (4) (2005) 193-215.

[26] L. Bourgeois, C. Dwyer, M. Weyland, J.-F. Nie, B.C. Muddle, Structure and energetics of the coherent interface between the $\theta^{\prime}$ precipitate phase and aluminium in $\mathrm{Al}-\mathrm{Cu}$, Acta Mater. 59 (18) (2011) 7043-7050.

[27] Z. Shen, Q. Ding, C. Liu, J. Wang, H. Tian, J. Li, Z. Zhang, Atomic-scale mechanism of the $\theta^{\prime \prime} \rightarrow \theta^{\prime}$ phase transformation in Al-Cu alloys, J. Mater. Sci. Technol. 33 (10) (2017) 1159-1164.

[28] C. Liu, Z. Ma, P. Ma, L. Zhan, M. Huang, Multiple precipitation reactions and formation of $\theta^{\prime}$-phase in a pre-deformed Al-Cu alloy, Mater. Sci. Eng.: A 733 (2018) 28-38.

[29] K. Matsuda, D. Teguri, T. Sato, Y. Uetani, S. Ikeno, Cu segregation around metastable phase in Al-Mg-Si alloy with Cu, Mater. Trans. 48 (5) (2007) 967-974.

[30] L. Ding, A. Orekhov, Y. Weng, Z. Jia, H. Idrissi, D. Schryvers, S. Muraishi, L. Hao, Q. Liu, Study of the Q' (Q)-phase precipitation in Al-Mg-Si-Cu alloys by quantification of atomic-resolution transmission electron microscopy images and atom probe tomography, J. Mater. Sci. 54 (10) (2019) 7943-7952.

[31] K.M. Knowles, W.M. Stobbs, The structure of $\{111\}$ age-hardening precipitates in Al-Cu-Mg-Ag alloys, Acta Crystallogr. Sect. B 44 (3) (1988) 207-227.

[32] M. Legros, G. Dehm, E. Arzt, T.J. Balk, Observation of giant diffusivity along dislocation cores, Science 319 (5870) (2008) 1646.

[33] C. Liu, S.K. Malladi, Q. Xu, J. Chen, F.D. Tichelaar, X. Zhuge, H.W. Zandbergen, In-situ stem imaging of growth and phase change of individual CuAlX precipitates in Al alloy, Sci Rep 7 (1) (2017) 2184.

[34] S. Wenner, C.D. Marioara, S.J. Andersen, M. Ervik, R. Holmestad, A hybrid aluminium alloy and its zoo of interacting nano-precipitates, Mater. Charact. 106 (2015) 226-231.

[35] I.J. Polmear, G. Pons, Y. Barbaux, H. Octor, C. Sanchez, A.J. Morton, W.E. Borbidge, $\mathrm{S}$. Rogers, After concorde: evaluation of creep resistant $\mathrm{Al}-\mathrm{Cu}-\mathrm{Mg}-\mathrm{Ag}$ alloys, Mater. Sci. Technol. 15 (8) (1999) 861-868.

[36] A. Garg, Y.C. Chang, J.M. Howe, Precipitation of the $\Omega$ phase in an Al-4.0Cu-0.5Mg alloy, Scr. Metall. Mater. 24 (4) (1990) 677-680.

[37] L.M. Wang, H.M. Flower, T.C. Lindley, Precipitation of the $\Omega$ Phase in 2024 and 2124 Aluminum Alloys, 1999.

[38] S.J. Kang, J.-M. Zuo, H.N. Han, M. Kim, Ab initio study of growth mechanism of omega precipitates in Al-Cu-Mg-Ag alloy and similar systems, J. Alloys Compd. 737 (2018) 207-212.

[39] G.B. Winkelman, K. Raviprasad, B.C. Muddle, Stimulation of the $\Omega$ phase in an $\mathrm{Al}-1.1$ at $\% \mathrm{Cu}-0.5$ at $\% \mathrm{Mg}$ alloy by a duplex ageing treatment involving initial natural ageing, Philos. Mag. Lett. 85 (4) (2005) 193-201.

[40] N. Ünlü, B.M. Gable, G.J. Shiflet, E.A. Starke, The effect of cold work on the precipitation of $\Omega$ and $\theta^{\prime}$ in a ternary Al-Cu-Mg alloy, Metall. Mater. Trans. A 34 (12) (2003) 2757-2769. 